UCRL-ID-124059

\title{
MONITORED PLUTONIUM AEROSOLS AT A SOIL CLEANUP SITE ON JOHNSTON ATOLL
}

\author{
Joseph H. Shinn \\ Cleo O. Fry \\ James Stephen Johnson \\ Air Pathway Assessment Team \\ Environmental Characterization Group \\ Health and Ecological Assessment Division \\ Lawrence Livermore National Laboratory
}

RECEVED

MAY 171980

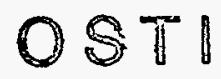

January 23, 1996

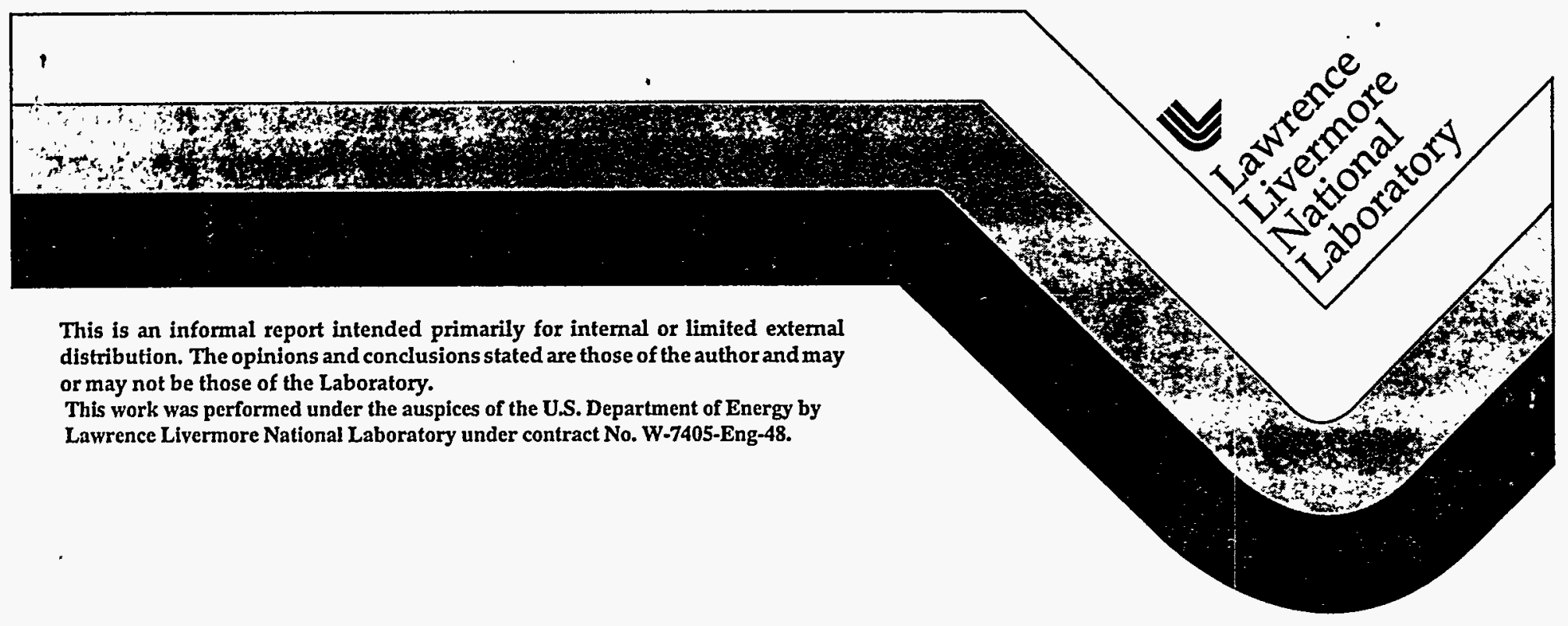

DISTRIBUTTON OF THIS DOCUMENT IS UNLLMTED

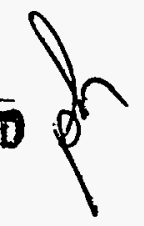




\section{DISCLAIMER}

This document was prepared as an account of work sponsored by an agency of the United States Government. Neither the United States Government nor the University of California nor any of their employees, makes any warranty, express or implied, or assumes any legal liability or responsibility for the accuracy, completeness, or usefulness of any information, apparatus, product, or process disclosed, or represents that its use would not infringe privately owned rights. Reference herein to any specific commercial product, process, or service by trade name, trademark, manufacturer, or otherwise, does not necessarily constitute or imply its endorsement, recommendation, or favoring by the United States Govemment or the University of Califomia. The views and opinions of authors expressed herein do not necessarily state or reflect those of the United States Government or the University of California, and shall not be used for advertising or product endorsement purposes.

This report has been reproduced directly from the best available copy.

Available to DOE and DOE contractors from the Office of Scientific and Technical Information

P.O. Box 62, Oak Ridge, TN 37831

Prices available from (615) 576-8401, FTS 626-8401

Available to the public from the

National Technical Information Service

U.S. Department of Commerce 5285 Port Royal Rd. Springfield, VA 22161 


\section{DESCLASIMISR}

Portions of this adocument may be illegible in electronic in inage products. Images are produced from the best available origind document. 


\title{
MONITORED PLUTONIUM AEROSOLS AT A SOIL CLEANUP SITE ON JOHNSTON ATOLL
}

\author{
Joseph H. Shinn \\ Cleo O. Fry \\ James Stephen Johnson
}

Air Pathway Assessment Team

Environmental Characterization Group

Health and Ecological Assessment Division

Lawrence Livermore National Laboratory

January 23, 1996 


\section{Table of Contents}

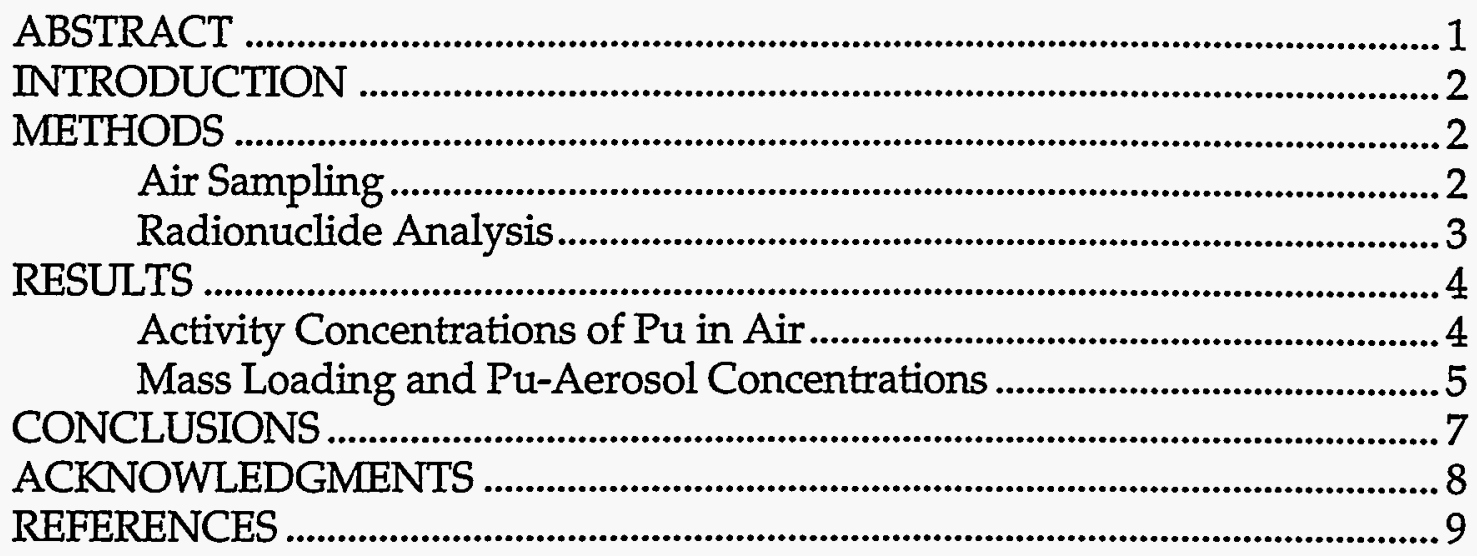

\section{List of Tables}

Table 1. Pu-Air Monitoring During Soil Sorting on Johnston Atoll, 1992-1995....5

Table 2. Summary of Workplace Pu-Concentrations on J.A., 1992-1995. ............... 8 


\section{MONITORED PLUTONIUM AEROSOLS AT A SOIL CLEANUP SITE ON JOHNSTON ATOLL.}

Abstract: Suspended plutonium in air was monitored for four periods near the operation of a stationary sorting system used to "mine" contaminated soil on Johnston Atoll. The monitoring periods were 14 Oct-14 Nov 1992, 20 Oct-15 Nov 1993, 16 Aug3 Nov 1994, and 17 Feb-27 Feb 1995. Pairs of high volume air samplers were located at each of four locations of the process stream: the "spoils pile" that was the feedstock, the "plant area" near the hot soil gate of the sorter, the "clean pile" conveyer area where sorted clean soil was moved, and the "oversize soil" crushing area. These locations were monitored only during the working hours, while air monitoring was also done at an upwind, "background" area 24-hours per day. The four monitoring locations were extremely dusty during 1993-1995, with median total suspended particulate mass loading of $1070 \mu \mathrm{g} / \mathrm{m}^{3}$ at the spoils pile, and maximum values of $5340 \mu \mathrm{g} / \mathrm{m}^{3}$ at the oversize soil site during this period, when background mass loadings were typically $23 \mu \mathrm{g} / \mathrm{m}^{3}$. Activity concentration of suspended Pu was $3.6 \mathrm{pCi} / \mathrm{g}$ in 1992, decreased to $0.43 \mathrm{pCi} / \mathrm{g}$ in 1993, and increased to 57 and $38 \mathrm{pCi} / \mathrm{g}$ in 1994 and 1995, respectively. This variation in activity concentration reflected the changing activity in the material being processed. The median concentrations of $P u$ in "workplace" air (combined spoils pile, plant area, and clean pile sites) in 1992 was $397 \mathrm{aCi} / \mathrm{m}^{3}\left(15 \mu \mathrm{Bq} / \mathrm{m}^{3}\right)$ ), but increased to median values of $23000 \mathrm{aCi} / \mathrm{m}^{3}\left(852 \mu \mathrm{Bg} / \mathrm{m}^{3}\right)$ in Aug-Nov 1994 and $29800 \mathrm{aCi} / \mathrm{m}^{3}$ $\left(1100 \mu \mathrm{Bg} / \mathrm{m}^{3}\right)$ in Feb 1995. The highest median value at the work sites $\left(29800 \mathrm{aCi} / \mathrm{m}^{3}\right)$ was more than 200 times lower than the regulatory level. The highest observed value was $84200 \mathrm{aCi} / \mathrm{m}^{3}$ at the spoils pile site, and this was more than 70 times lower than the regulatory level. The conclusion was that, in spite of the dusty environment, and the increased level of specific activity, we did not find that the soil processing posed any significant risk to workers during the observation periods 1992-1995. 


\section{INTRODUCTION}

We monitored the air concentrations for suspended Pu-aerosol $(239,240 \mathrm{Pu})$ during four separate periods of soil cleanup operation at Johnston Atoll from October 1992 to February 1995. The soil cleanup operation consisted of sorting the soil contaminated by plutonium $(\mathrm{Pu})$ at Johnston Atoll, to produce soil clean enough for use in landfills while removing the high-activity, small soil volumes that are then disposed as waste (Bramlitt, 1993). This report provides results of the measurements of total suspended particulates in mass-loading $\left(\mu \mathrm{g} / \mathrm{m}^{3}\right)$, mass-specific $\mathrm{Pu}$-aerosol activity concentration $(\mathrm{pCi} / \mathrm{g})$, and $\mathrm{Pu}$ concentration in air $\left(\mathrm{aCi} / \mathrm{m}^{3}\right)$. A previous study in 1992 by us (Shinn, Fry, and Johnson, 1994) provides additional details, such as particle-size and enhancement factor data.

\section{METHODS}

\section{Air Sampling}

Two high-volume air samplers (HV) were operated as a set at each of four separate locations during the working hours near the stationary soil-sorting system. Also, two "background" HV were operated continuously, together, at an upwind location, away from the soil contamination site. The HV were powered by a motor-blower unit mounted on a filter holder (General Metal Works, Inc., Model FH-2100), and cellulose fiber filters (8- $\times 10$-inch, Whatman 41$)$ were used. This filter material is qualified by the American National Standards Institute, ANSI Standard N13.1 (reaffirmed 1993). At the face velocities in this application, for a test aerosol at $0.3 \mu \mathrm{m}$ aerodynamic diameter Whatman 41 has $70 \%$ efficiency for fragmenting liquid aerosols and $92-94 \%$ efficiency for solid aerosols. For larger particles, it has efficiencies greater than $98 \%$. Cellulose fiber is preferred to reduce the effort required for acid dissolution after filter exposure, but to measure mass loading a special effort was required to weigh the filters (after equilibration at a reference temperature and humidity) because of the hygroscopic nature of the media. The motor-blowers (General Metal Works, Inc) were operated for periods up to one month at a flow rate of $34 \mathrm{~m}^{3} / \mathrm{h}$. Flow rates and lapsed times were recorded daily, and flow rates were maintained by adjusting a variable autotransformer on each motor (VARIAC, Model 3PN116B, Superior Electric $\mathrm{Co}$.) Flow rates were monitored at a pressure tap on the motorblower using a dial manometer (Magnhelic Model 2002C). Calibration of the flow rates was performed in the laboratory using a transfer-standard orifice assembly (General Metal Works, Inc., Model GMW-25), which provided a linear 
curve of flow rate versus the square root of pressure. Each motor was checked in the laboratory to see that it was leak-free and delivered a flow within $5 \%$ of the calibration for $34 \mathrm{~m}^{3} / \mathrm{h}$ at sea level. The $H V$ were installed on portable tripod assemblies (General Metal Works, Inc., Model GT2200) and operated approximately $8 \mathrm{~h}$ per day during the working period. An operator covered the units with plastic bags for the periods when they were on standby. Details of $\mathrm{HV}$ air-sampler operating procedure are provided in "Protocols of Radiocontaminant Air Monitoring for Inhalation Exposure Estimates", (Shinn, 1995).

Four monitoring periods during operations of the cleanup (soil sorting) activities were: (1) 14 Oct to 14 Nov 1992, (2) 20 Oct to 15 Nov 1993, (3) 16 Aug to 3 Nov 1994, and (4) 17 Feb to 27 Feb 1995. The first period was reported earlier (Shinn, Fry, and Johnson, 1994). The third period was interrupted by a hurricane so that the sampling period was 16 Aug to 23 Aug and restarted, 30 Oct to $3 \mathrm{Nov}$ 1994. (The air samplers were only operated when the sorting system was working.)

The "spoils pile" (SP) set of HV units was located near the feedstock where the contaminated soil was initially dumped onto a screen. The "plant area" (PA) set of HV units was located at the sorter hot soil gate near where containers were filled with the high Pu-activity soil. The "clean pile" (CP) set of HV units was located near the base of the conveyer unit that moved the sorted soil after it had passed successfully through the detector units. See the description of this facility for the "mining" of $\mathrm{Pu}$ provided by Bramlitt (1993). In addition, the "oversize soil" (OS) set of HV units were operated near a rock crusher that was used intermittently. The "background" HV units were operated continuously, $24 \mathrm{~h}$ per day for each period, and were located upwind where no $\mathrm{Pu}$ soil contamination could be found. The background HV filters were changed at the same time as other air samplers.

\section{Radionuclide Analysis}

Radiochemical methods were utilized to determine the $239,240 \mathrm{Pu}, 238 \mathrm{Pu}$, and $241 \mathrm{Am}$ on aerosol particles impacted on the cellulose fiber substrate. Our minimum detectability limit was less than $0.3 \mathrm{pCi}(0.01 \mathrm{~Bq})$ per sample for these transuranic isotopes. The isotopes were recovered by acid total-dissolution, ionexchange separation, and electrodeposition, and measured by alpha spectrometry using internal chemical yield tracers of $242 \mathrm{Pu}$ and $243 \mathrm{Am}$. These methods are in extensive use in our studies (Shinn, 1993) of contamination sites around the world: Marshall Islands (Bikini, Enewetak, and Rongelap), Nevada Test Site (GMX, Little Feller, Palanquin, and Plutonium Valley), TonopahNevada (Roller Coaster sites), Savannah River Lab-South Carolina (H Area), 
Lawrence Livermore National Lab-California (Pu-garden site), ChernobylUkraine (sandy beach site, near Nuclear Power Plant Unit 4), and PalomaresSpain (site of 1966 aircraft accident). Details of the protocol are provided in "Radiochemical Procedures for Analysis of Pu, Am, Cs, and Sr in Water, Soil, Sediments, and Biota Samples", (Wong et al, 1995).

Quality assurance was carried out through adherence to established protocols, (Kehl et al, 1995) and by use of quality control procedures (blank filters, control filters-carried to the site and back without use, and standards). Analytical accuracy has been maintained among these methods for the analysis of $\mathrm{Pu}$ (from atmospheric fallout) in shallow or deep marine sediments or in soil and sediment samples collected from the Pacific Test Sites at Bikini and Enewetak Atolls (close-in fallout). Our method has also been used in the analysis of $\mathrm{Pu}$ in NIST Radioactivity Standard Reference Materials (Rocky Flats Soil and Columbia River Sediment) and in IAEA interlaboratory comparison samples.

\section{RESULTS}

\section{Activity Concentrations of $\mathrm{Pu}$ in Air}

The median activity concentration of $\mathrm{Pu}$ in the suspended aerosols at the soil cleanup work site (combined SP, PA, and CP) was $3.64 \mathrm{pCi} / \mathrm{g}(135 \mathrm{~Bq} / \mathrm{Kg}$ ) in Oct-Nov 1992, as noted in the previous study (Shinn, Fry and Johnson, 1994). The changes we observed in subsequent monitoring of activity concentration probably reflects the changes in the activity of soil material processed. The median work-site activity concentration decreased to $0.43 \mathrm{pCi} / \mathrm{g}$ in Oct-Nov 1993, but increased to $57 \mathrm{pCi} / \mathrm{g}$ in the period Aug-Nov 1994, and to $38 \mathrm{pCi} / \mathrm{g}$ in Feb 1995. These median values are calculated from the data of Table 1, except for the 1992 case where the data are obtained from a larger data set reported by Shinn, Fry and Johnson, 1994. The estimate of the median in the cases of 1993, 1994 , and 1995, was obtained by determining the geometric mean, for example the cube root of the product of three measurements at SP, PA, and CP.

The specific activity of suspended aerosols in the vicinity of the oversize soil crusher (OS) was always much less than in the other work areas. At OS the specific activity of suspended Pu was $0.14 \mathrm{pCi} / \mathrm{g}$ in Oct-Nov 1993, but increased to $2.5 \mathrm{pCi} / \mathrm{g}$ in Aug-Nov 1994, and to $7.7 \mathrm{pCi} / \mathrm{g}$ in Feb 1995; see Table 1. It was noted also that the specific activity of suspended $\mathrm{Pu}$ was slightly less near the clean pile $(\mathrm{CP})$ than at the two work sites near the spoils pile and the plant area (SP and PA) except for 1992 when one air sample had unusually high values. 
Table 1. Pu-Air Monitoring During Soil Sorting on Johnston Atoll, 1992-1995.

\begin{tabular}{ccccc}
\hline $\begin{array}{c}\text { Monitoring } \\
\text { location }\end{array}$ & $\begin{array}{c}\text { Monitoring } \\
\text { period }\end{array}$ & $\begin{array}{c}\text { Pu } \\
\text { Activity } \\
(\mathrm{pCi} / \mathrm{g})\end{array}$ & $\begin{array}{c}\text { Pu } \\
\text { in Air } \\
\left(\mathrm{aCi} / \mathrm{m}^{3}\right)\end{array}$ & $\begin{array}{c}\text { Mass } \\
\text { Loading } \\
\left(\mu \mathrm{g} / \mathrm{m}^{3}\right)\end{array}$ \\
\hline \multirow{2}{*}{ Spoils Pile } & 14 Oct-14 Nov 1992 & 4.3 & 795 & 184 \\
& 20 Oct-15 Nov 1993 & 0.48 & 609 & 1280 \\
& 16 Aug-3 Nov 1994 & 81 & 45200 & 555 \\
& 17 Feb-27 Feb 1995 & 48 & 84200 & 1740 \\
Plant Area & 14 Oct-14 Nov 1992 & 3.4 & 322 & 94 \\
& 20 Oct-15 Nov 1993 & 0.44 & 105 & 238 \\
& 16 Aug-3 Nov 1994 & 93 & 42100 & 454 \\
& 17 Feb-27 Feb 1995 & 34 & 30600 & 888 \\
Clean Pile & 14 Oct-14 Nov 1992 & 9.2 & 689 & 82 \\
& 20 Oct-15 Nov 1993 & 0.37 & 73 & 199 \\
& 16 Aug-3 Nov 1994 & 24 & 6410 & 268 \\
& 17 Feb-27 Feb 1995 & 33 & 10300 & 315 \\
Oversize Soil & 14 Oct-14 Nov 1992 & - & & \\
& 20 Oct-15 Nov 1993 & 0.14 & 753 & 5340 \\
& 16 Aug-3 Nov 1994 & 2.5 & 1670 & 655 \\
& 17 Feb-27 Feb 1995 & 7.7 & 31800 & 4130 \\
Background & 14 Oct-14 Nov 1992 & 0.14 & 5.8 & 41 \\
& 20 Oct-15 Nov 1993 & 0.066 & 1.3 & 19 \\
& 16 Aug-3 Nov 1994 & 0.61 & 20.3 & 34 \\
& 17 Feb-27 Feb 1995 & 0.36 & 7.0 & 19 \\
\hline
\end{tabular}

\section{Mass Loading and Pu-Aerosol Concentrations}

The total suspended particulate mass loading for the work area (SP, PA, and CP) increased significantly from a median of $109 \mu \mathrm{g} / \mathrm{m}^{3}$ in Oct-Nov 1992. Over the three monitoring periods in 1993 to 1995, the median TSP mass loading at SP was $1070 \mu \mathrm{g} / \mathrm{m}^{3}$, compared to $458 \mu \mathrm{g} / \mathrm{m}^{3}$ at PA and $256 \mu \mathrm{g} / \mathrm{m}^{3}$ at CP. But when the rock crusher was operating, the median total suspended particulates value at OS was $2440 \mu \mathrm{g} / \mathrm{m}^{3}$ and it was by far the more dusty site. By comparison, the upwind background HV measured a median $23 \mu \mathrm{g} / \mathrm{m}^{3}$ for the 1993-1995 period, and a significant portion of that mass loading would be due to the concentration of sea salt particulates. The Clean Air Act standard for TSP mass loading is $150 \mu \mathrm{g} / \mathrm{m}^{3}$ over a $24 \mathrm{~h}$ period.

The Pu-concentrations of suspended particulates during the monitoring period varied both due to the amount of dust suspended in the work areas, and due to the activity of the soil. Multiplying the mass loading by the activity concentrations, we obtained the 239,240Pu-aerosol concentration. See Figure 1. 


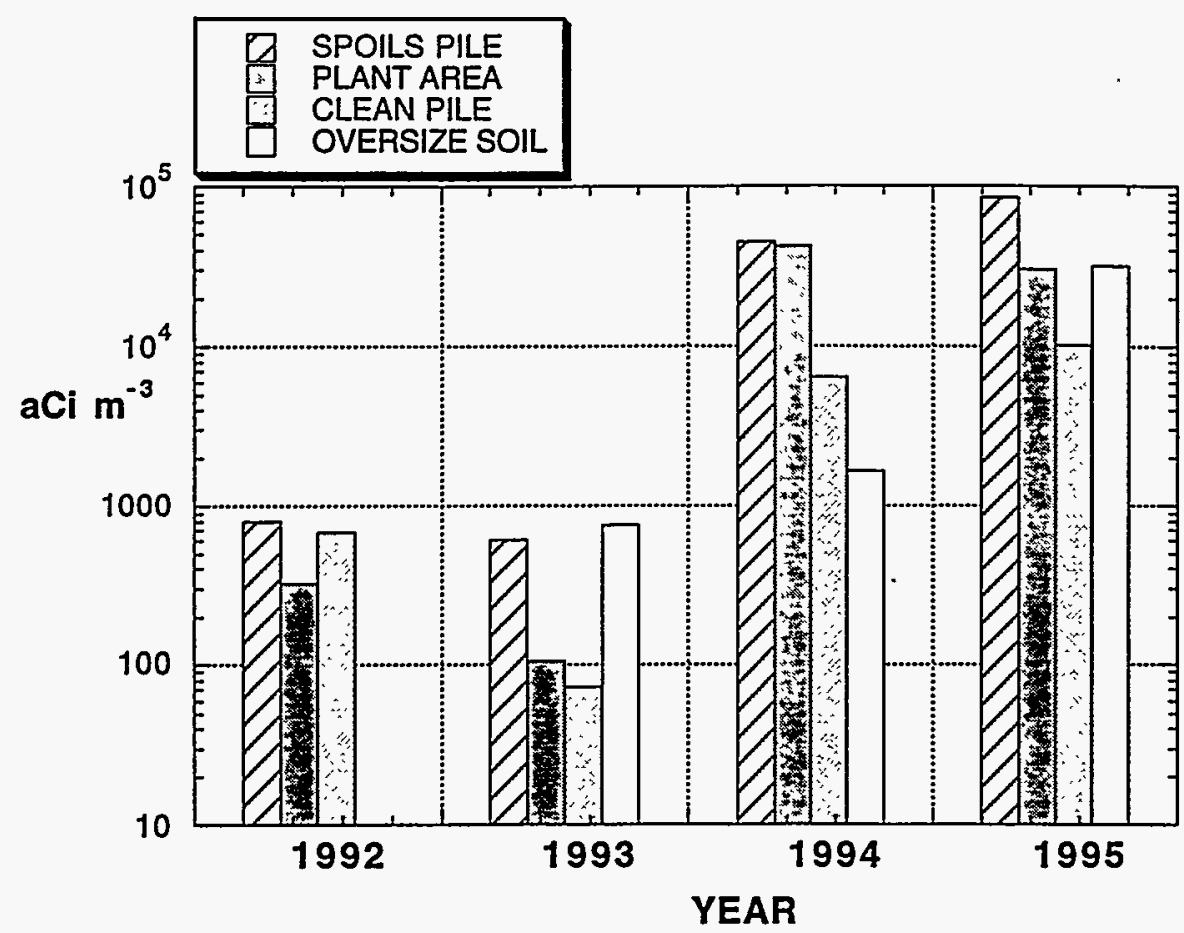

Figure 1. $\mathrm{Pu}$ in air $\left(\mathrm{aCi} / \mathrm{m}^{3}\right)$ during soil sorting operations at Johnston Atoll.

In 1992 the median concentration in the work sites (SP, PA, and CP) was $397 \mathrm{aCi} / \mathrm{m}^{3}\left(15 \mu \mathrm{Bq} / \mathrm{m}^{3}\right)$ for the period 14 Oct-14 Nov. The values of $\mathrm{Pu}$ in air ranged then from 280 to $1508 \mathrm{aCi} / \mathrm{m}^{3}\left(10\right.$ to $\left.56 \mu \mathrm{Bq} / \mathrm{m}^{3}\right)$. The $\mathrm{Pu}$ concentration in air at the work sites decreased to median values of $168 \mathrm{aCi} / \mathrm{m}^{3}$ in Oct-Nov 1993 , but increased to median values of $23000 \mathrm{aCi} / \mathrm{m}^{3}\left(852 \mu \mathrm{Bq} / \mathrm{m}^{3}\right)$ in Aug-Nov 1994 and $29800 \mathrm{aCi} / \mathrm{m}^{3}\left(1100 \mu \mathrm{Bq} / \mathrm{m}^{3}\right)$ in Feb 1995. (In the 1992 case the median is calculated from a larger data set reported by Shinn, Fry and Johnson, 1994. The estimate of the median in the cases of 1993, 1994, and 1995, was obtained by determining the geometric mean, for example the cube root of the product of three measurements at $\mathrm{SP}, \mathrm{PA}$, and $\mathrm{CP}$.)

The spoils pile (SP) produced during 1993-1995 the highest Pu concentrations in air of all the work sites with a median $\mathrm{Pu}$ concentration of $13200 \mathrm{aCi} / \mathrm{m}^{3}$ $\left(490 \mu \mathrm{Bq} / \mathrm{m}^{3}\right)$ and a range from $609 \mathrm{aCi} / \mathrm{m}^{3}$ to $84200 \mathrm{aCi} / \mathrm{m}^{3}$. The clean pile $(\mathrm{CP})$ had the lowest median $\mathrm{Pu}$ concentration of $1690 \mathrm{aCi} / \mathrm{m}^{3}\left(63 \mu \mathrm{Bq} / \mathrm{m}^{3}\right)$. The 
median value for the $O S$ site near the rock crusher was $3420 \mathrm{aCi} / \mathrm{m}^{3}$ (127 $\mu \mathrm{Bq} / \mathrm{m}^{3}$ ) over the 1993-1995 period; higher mass loadings of total suspended particulates was counterbalanced by the lower activity of the particulates at the OS site. The rock crusher at OS site was operated $60 \%$ of the normal working hours during the test period, 1993-1995.

In 1992 the upwind, background mean 239,240Pu-aerosol concentration was $5.8 \mathrm{aCi} / \mathrm{m}^{3}\left(0.21 \mu \mathrm{Bq} / \mathrm{m}^{3}\right)$. The median value for the background over the 19931995 period was $5.6 \mathrm{aCi} / \mathrm{m}^{3}$, with a range from 1.3 to $20 \mathrm{aCi} / \mathrm{m}^{3}$.

\section{CONCLUSIONS}

The work area certainly was a dusty environment, with median total suspended particulate levels that exceeded the Clean Air Act standard of $150 \mu \mathrm{g} / \mathrm{m}^{3}$. during most of the work hours, and reached median levels of 787 $\mu \mathrm{g} / \mathrm{m}^{3}$ in 1995 . The spoils pile area (median total suspended particulate mass loading of $1070 \mu \mathrm{g} / \mathrm{m}^{3}$ ) was more dusty than the plant area or the clean pile area. But the dust in the vicinity of the rock crusher at the oversize soil site was the worst with a median level of $2440 \mu \mathrm{g} / \mathrm{m}^{3}$ and a maximum of $5340 \mu \mathrm{g} / \mathrm{m}^{3}$ during the 1993-1995 observation periods.

Results of air monitoring for suspended Pu over the four periods in 1992-1995 during operation of a stationary soil sorting system on Johnston Atoll showed that there should be no high risk from worker exposure. Earlier studies (Shinn, Fry, and Johnson, 1994) showed that the median aerodynamic diameter of suspended mass and Pu-activity was $3.4 \mu \mathrm{m}$ and would be in the middle of the "respirable" range. The concentration guide for radiation protection of workers exposed to $239,240 \mathrm{Pu}$ (Lung Retention Class $\mathrm{Y}$ ) is $6,000,000 \mathrm{aCi} / \mathrm{m}^{3}$ $\left(2220 \mu \mathrm{Bq} / \mathrm{m}^{3}\right)$. This value is set by U.S. Department of Energy, in Federal Rule 10 CFR Part 835 (Federal Register, December 14, 1993.). The highest median value at the work sites (SP, PA, and CP) during the 1992-1995 monitoring period was $29800 \mathrm{aCi} / \mathrm{m}^{3}$ during Feb 1995, and this was more than 200 times lower than the regulatory level. The highest observed value was $84200 \mathrm{aCi} / \mathrm{m}^{3}$ at the spoils pile site, and this was more than 70 times lower than the regulatory level. Therefore, we do not find that the soil processing poses any significant risk to workers. See Table 2. 
Table 2. Summary of Workplace Pu-Concentrations on I.A., 1992-1995.

Median Values in the Spoils Pile, Plant Area, and Clean Pile Work Area.

\begin{tabular}{|c|c|c|c|}
\hline $\begin{array}{l}\text { Monitoring } \\
\text { location }\end{array}$ & $\begin{array}{l}\text { Monitoring } \\
\text { period }\end{array}$ & $\begin{array}{c}\mathrm{Pu} \\
\left.\text { in } \mathrm{Air}_{(\mathrm{aC}} / \mathrm{m}^{3}\right) \\
\end{array}$ & $\begin{array}{c}\text { Mass } \\
\text { Loading } \\
\left(\mu \mathrm{g} / \mathrm{m}^{3}\right) \\
\end{array}$ \\
\hline $\begin{array}{c}\text { Work Area } \\
(\mathrm{SP}, \mathrm{PA}, \text { and } \mathrm{CP})\end{array}$ & $\begin{array}{l}14 \text { Oct-14 Nov } 1992 \\
20 \text { Oct-15 Nov } 1993 \\
16 \text { Aug-3 Nov } 1994 \\
17 \text { Feb-27 Feb } 1995\end{array}$ & $\begin{array}{c}397 \\
168 \\
23000 \\
29800\end{array}$ & $\begin{array}{l}109 \\
393 \\
407 \\
787\end{array}$ \\
\hline Background & 1992-1995 median & 5.7 & 27 \\
\hline Federal Standards & & $6,000,000$ & 150 \\
\hline
\end{tabular}

\section{ACKNOWLEDGMENTS}

This study was supported by the Defense Nuclear Agency, Kirtland Air Force Base, Albuquerque, New Mexico (Dr. E. T. Bramlitt, and Major Joseph Kimbrell). We wish to thank members of the Health and Ecological Assessment Division, Lawrence Livermore National Laboratory: Dr. William Robison, Principal Investigator, Marshall Island Radioecology Program, for his technical and logistical support, and Terry Jokela, Kai M. Wong and Henry E. Jones for their plutonium radiochemistry. 


\section{REFERENCES}

1. Bramlitt, E.T., 1993, Experience in Mining Plutonium for Soil Cleanup, p 27-32, in Proceedings of the 1993 International Conference on Nuclear Waste Management and Environmental Restoration, Prague, Czech Republic, Sept. 5-11, 1992, Vol. 2, eds. P.-E. Ahlstroem, C. C. Chapman, R. Kohout, and J. Marek, American Society of Mechanical Engineers, 345 47th St., United Engineering Center, New York, N.Y., 10017.

2. Shinn, J. H., C. O. Fry, and J. S. Johnson, 1994, Suspended Plutonium Aerosols Near a Soil Cleanup Site on Johnston Atoll in 1992, Technical Report UCRL-ID116495, Lawrence Livermore National Laboratory.

3. Shinn, J. H., 1995, Protocols of Radiocontaminant Air Monitoring for Inhalation Exposure Estimates, Technical Report UCRL-ID-122254. Lawrence Livermore National Laboratory.

4. Shinn, J. H., 1993, The Technical Basis for Air Pathway Assessment of Resuspended Radioactive Aerosols: LLNL Experiences at Seven Sites Around the World, Technical Report UCRL-JC-115045, Lawrence Livermore National Laboratory, presented at Topical Workshop on the Technical Basis for Measuring, Modeling, and Mitigating Toxic Aerosols, Albuquerque, NM, Sept 27-30, 1993.

5. Wong, K. M, T. A. Jokela, and V. E. Noshkin, 1995, Radiochemical Procedures for Analysis of Pu, Am, Cs, and Sr in Water, Soil, Sediments, and Biota Samples, Technical Report UCRL-1D-116497, Lawrence Livermore National Laboratory.

6. Kehl, S. R., M. E. Mount, and W. L. Robison, 1995, The Northern Marshall Islands Radiological Survey: A Quality Control Program for Radiochemical and Gamma Spectroscopy Analysis, Technical Report UCRL-ID-120429, Lawrence Livermore National Laboratory. 